\title{
Germany minister backs genome research
}

Heidelberg. Germany's research minister, Jürgen Rüttgers, speaking this week at the German Cancer Research Centre (DKFZ), promised that Germany will catch up with the rest of the world in genetics research by the end of the decade.

But Rüttgers disappointed both journalists and scientists by announcing that he was not able officially to launch Germany's new genetics research programme, expected to be worth DM50 million (US\$72 million) a year for eight years, as planned.

The delays have apparently been caused by last-minute concern within the research ministry over the level of industry's contribution to the financing of the programme.

Despite excellent research facilities and generous funding, public resistance stemming from the Nazi period has kept Germany behind countries such as the United States, the United Kingdom and France in genetics research.

But Rüttgers said that public opinion is now changing, and that although the potential use of genetic engineering in the food and agricultural industries continues to be viewed with great suspicion, there is good

acceptance of the value of such techniques in medicine.

He added that are also signs that German industry has at last got its foot in the door. Although it has only four genetically engineered medicinal products on the market, compared to 80 in Japan and 130 in the

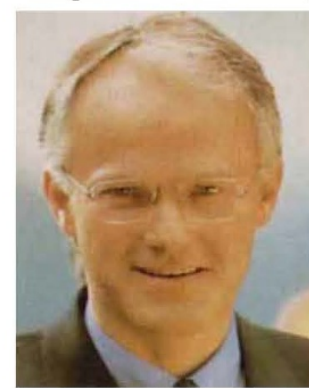

Rüttgers: 'public views are changing'. diagnostic tools and therapies for human diseases, even though in practice such applications are quite distant from the programme's main aim.

That is to develop a national genetic resource centre to provide scientists with genetic probes for localizing and identifying genes (see Nature 375, 175; 1995). German scientists, in academic or industrial institutes, will receive them free of charge, on condition that they provide all of their data to the centre; a charge will be made for non-German scientists and industry.

Critics have argued that Germany may be offering too little, too late, and that it has little hope of catching up other countries certainly not within five years. But Rüttgers expressed optimism, pointing out the recent change of public attitudes, as well as a relaxation of regulations on genetics research, which had previously required a disheartening amount of paperwork from researchers.

Rüttgers refused to be drawn on whether he would shift funds from other areas into genetics research. But he emphasized that he is a staunch defender of basic research, pointing out that when he took office last November, he became embroiled in an acrimonious debate about whether Germany should transfer funds from basic to applied research, but failed to find any reason for doing so.

Alison Abbott

\section{Physicist will sue Internet providers over 'libellous' remarks}

London. A British physics lecturer who last week accepted out-of-court damages in Britain's first Internet libel case now intends to issue libel writs against two Internet providers in the United States and Canada.

Laurence Godfrey, who secured a "substantial" payment from Philip HallamBaker, a nuclear physicist formerly working at CERN in Geneva, over remarks about his professional work posted on Usenet, is preparing legal action against a university in Canada and a private Internet accessprovider in the United States. Both organizations, he claims, have refused requests to censor remarks posted from their sites that he believes are defamatory.

"I have written to the organizations on several occasions," says Godfrey. "If they had an apology [from those who had made the original remarks] and promised not to allow the remarks to be repeated on their networks, I was happy to let the matter drop. This has not happened, which leaves me with no option to sue for libel in order to clear my name." Both organizations, which Godfrey is refusing to name, have said they will defend any proposed action.

Nick Braithwaite, a lawyer with Londonbased international law firm Clifford Chance, says that although the resolution of the UK case does not establish any legal precedent - in particular whether his remarks should be judged by the laws of libel or slander - one explanation of the decision by Hallam-Baker's lawyers to with- draw is the thought they would lose.

Nonetheless, Godfrey's suit against Hallam-Baker was based on personal libel. The absence in either the United States or Canada of legislation on Internet libel makes the prospects of legal action against Internet-providers uncertain.

Editorial interference on the Internet is a sensitive issue. Most US bodies that provide access to the Internet regard any interference as a violation of free expression (see Nature 374, 297; 1995)

Internet libel cases, though rare, are not unknown. In 1991, a federal judge in New York decided that the online service Compuserve could not be sued for libel when it unknowingly let defamatory comments remain on one of its bulletin boards. The judge is understood to have made his ruling on the basis that Compuserve, which exercised no editorial control, was an innocent party, and could not be treated as the publisher of the material.

But in a another case last month, the US investment bank Stratton Mount scored a partial victory in its $\$ 200$-million libel case against the proprietary online service Prodigy for allowing allegedly scurrilous remarks about the bank to be posted on a bulletin board by a subscriber.

In an interim, pre-trial judgement in May, the New York State Court judge ruled that Prodigy's status during the hearing would be as publisher of the material, and not as an innocent carrier of information.
According to Robert Carolina, also of Clifford Chance, "the reasons for this were that Prodigy openly advertised that they exercise editorial control over material available to subscribers". But he adds that an equally important issue - whether the statement can be considered defamatory has yet to be resolved.

Internet libel has had less exposure in the United Kingdom. But one university said it would not wait for a court decision before removing material posted on a bulletin board that appeared defamatory. "If something looked defamatory, says Roland Rosner, director of the Information Systems Division at University College London, "I'd consult lawyers first and, if need be, remove it on the grounds that Internet access at UCL is for academic purposes only."

But private operators consider policing the Internet to be an unprofitable tier of administration. "It's just too complicated," says Steve Kennedy of Demon Internet, an organization that provides its subscribers with unrestricted access to Internet. "I can't employ hundreds of people to wade through half a gigabyte of news each day," he says.

The UK government will introduce draft legislation later this year to protect innocent' Internet providers from being sued for defamatory material passing through or held on bulletin boards - " assuming they did not know of its defamatory nature", according to a spokesman for the Lord Chancellor's Department.

Ehsan Masood 